\title{
The strategic capability of Asian network airlines to compete with low-cost carriers
}

\author{
James Pearson $^{1^{*}}$, John F. O’Connell ${ }^{2}$, David Pitfield ${ }^{1}$, Tim Ryley ${ }^{1}$ \\ ${ }^{I}$ Transport Studies Group, Loughborough University, Loughborough, LE11 3TU, UK \\ ${ }^{2}$ Centre for Air Transport, Cranfield University, Martell House, Bedford, MK43 OTR, UK
}

\begin{abstract}
:
Never before have network airlines been so exposed and vulnerable to low-cost carriers (LCCs). While LCCs had 26.3\% of all world seats in 2013, Southeast Asia had 57.7\% and South Asia 58.4\% - and these figures will only increase. There are many consequences of LCCs on network airlines, including inadequately meeting the expectations of customers, so increasing dissatisfaction, and not offering sufficient value-for-money. Clearly, it is fundamentally important for Asian network airlines to respond appropriately to LCCs. This paper looks at the strategic capability of 22 of the top Asian network airlines in competing with LCCswhich is achieved by analysing questionnairedata from these airlines in terms of 37 competitive responses across six distinct response categories. This paperalso investigates how strategic capability varies by Asian sub-region and by airline performance, with performance based upon eight different performance areas. The results show that strategic capability varies widely, with Vietnam Airlines possessing the strongest strategic capability and SilkAir the weakest. Of others that compete heavily with LCCs, Malaysia Airlines and Garuda Indonesia have strong capabilities, while Philippine Airlines does not. As a whole, network airlines within Southeast Asia have the greatest strategic capability, andNortheast Asia the weakest. There is a reasonably strong correlation of between strategic capability and overall performance, which suggests that those airlines with strong strategic capability should achieve strong overall performance.
\end{abstract}

Keywords: Competition, competitive responses, Asia, network airlines, low-cost carriers

\section{Introduction}

Never before have network airlines, or full-service airlines, been so exposed and vulnerable to low-cost carriers (LCCs) with Doganis (2006, p.22) suggesting that: "the most threatening challenge to be faced will be the irresistible rise of the low-cost sector." In recent times, this has been particularly evident in Asia due to expanding open skies, rising disposable incomes within fast-growing economies, and often large populations yet comparatively poor surface transport (Torr, 2014). While LCCs seats represented $26.3 \%$ of all seats worldwide in 2013, they represented 57.7\% in Southeast Asia and 58.4\% in South Asia (CAPA, 2014). Northeast Asia lagged with just 9.3\%, but this is inevitably going to rise as open skiesare increasingly becoming legislated; while a political mind-set, notably in China, is beginning to embrace and encourage the continued development and expansion of LCCs to advance economic prosperity (Airline Leader, 2013).As a whole, Asia-Pacific

\footnotetext{
*Corresponding author. Tel.: +07896 003258
}

E-mail address:j.pearson@lboro.ac.uk 
represented $29 \%$ of worldwide revenue passenger kilometres (RPKs) in 2012, which is forecasted to grow to $34 \%$ by 2032 (Airbus, 2013).

Doganis $(2006$, p.12) reasoned that "the most significant trend [for airlines] has been the gradualliberalisation of international air transport...with profound effects on both market structure and operating patterns." Thus,many barriers-to-entry reduce which facilitates the entry of new, nimble, and lower-cost competitors, and which therefore produces formidable challenges for legacy operators. Indeed, the rise of LCCs has "potentially crippling circumstances" (CAPA, 2009) for network airlines within short- and medium-haul markets.

Hanaoka et al (2014) found that the entry of one Asia-based LCC on one route may affect the fare, frequency, and profitability of related competitive routes for the entire network. Clearly, there are enormous challenges facing Asian network airlines as to how they effectively respond to LCCs. Therefore, a critical and unanswered question looms - just how capable are Asian network airlines in competing with LCCs? Given the current growth of LCCs in Asia and the pending enlargement partly as a result of ASEAN open skies set for implementation by 2015 , the threats facing incumbents are to escalate even further (Tan, 2014; Fu and Oum, 2014). Thus, this paper seeksto establish the strategic capability of Asian network airlines, how their strategic capability varies by sub-region within Asia, and whether airline performance differs by strategic capability.

\section{Existing literature}

Embedded ideologies of LCCs include a lower average price, an increased emphasis on value-for-money, and empowering the customer with an additional range of airline choice in the form of low fares and unbundled products. The literature is replete with the shortcomings of the full service airlines as they have inadequately met the expectations of the short-haul market segments, and the resulting dissatisfaction, largely attributable to cross-price elasticity, has triggered many passengers to switch to LCCs.Ultimately, the price of the ticket has been the key decision-making determinant, which has shifted enormous volumes of traffic towards the lean business models of LCCs, while at the same time stimulating new traffic influxes. Subsequently, network airlines havereacted by removing layersof cost in order to induce lower fares, which overall reduced yields, but was counteracted by an increase in traffic and load factors.

"Low-cost carriers represent an increasing and significant threat to the long-term viability of legacy airlines" (Taneja, 2010, p.xxxiii). O'Connell (2007) stated that the ability of LCCs 
to offer an adequate portion of their service quality at less than 50 per cent of the cost of network airlinesjeopardises the future of network carriers in short-haul markets. This is further strengthened by Merkert and Pearson (2014) finding that an insignificant relationship exists between service quality, a key part of the proposition of network airlines, and airline profitability.

Yet Ryans (2009, p.14) is adamant: "The emergence of low-cost competition is certainly not all bad news for traditional companies." This is because it frequently means that there is a sizeable segment of a market that is not sufficiently satisfied with the value propositions of incumbent firms- such customers seek 'good enough' products at low prices. While these customers may lack meaningful purchasing power on an individual basis vis-à-vis those customers with greater incomes and greater willingness and ability to spend more, they may collectively represent a considerable market opportunity (Ryans, 2009). Some management at existing firms may recognise the emerging opportunity that is presented and may take the time and effort to learn from their low-cost competitors for their own benefit. They may realise that new entrants with lower costs, lower prices, straightforward propositions and value-for-money initiatives may be forthcoming and have an opportunity to act expeditiously which is anappropriate response in today's fast paced marketplace (Roberts and Stockport, 2014).

Yet management in legacy companies are laggards and this lack of agility causes many problems. Ryans (2009, p.83) reverberates this theme by stating "one of the toughest decisions executives in traditional companies face today is whether to respond to their lowcost competitors, and, if so, what should be the timing and extent of that response." Theseshortcomings can have enormous ramifications coupled with an unwillingness to believe that the threat is real or will have severe impacts (Hamel and Prahalad, 2013). The short/medium-haul sectors of the network airlines are facing increasingly treacherous problems when confronting the relentless growth and evolution of LCCs as they continue to attack and penetrate the incumbents' core markets. Evidence from both the academic and commercial worlds clearly shows that evolving LCCs are increasingly targeting higheryielding business travellers as they are offering enhanced differentiated products from costeffective platforms at prices lower than the legacy competitors in order to capture a higher PRASM (passenger revenue per available seat mile), which is damaging and threatening to network airlines (Klophaus et al, 2012; Airline Leader, 2012)

The threat posed by LCCs varies in intensity. This depends upon whether LCCs are emerging, growing, or evolving, with Gross and Luck (2013) arguing that network airlines 
faced with LCCs in all three positions are in a particularly precarious situation as strategies must be implemented by network airlines at each stage to counteract and circumvent these situations. Rumelt (2011) finds that the objectives of firms are often a secondary consideration in the design of response strategies, while Markides (2006)argues that the threats posed by low-cost competitors should be based upon a firm's objectives, resources, and core competencies. Taneja et al (2014) insists that threats should not be the foundation to strategy formation, while Dutton and Jackson (1987) believe that strategic responses must change according to the intensity and timing of aspecific threat. The degree and nature of responses by network airlines to LCCs will depend upon the evolving strategies(e.g. assigned seating, code-sharing activities, and greater use of primary airports) and likely future action of LCCs.

Against increasing competitive challenges for Asian network airlines, thispaper is structured as follows. Section 3 provides a comprehensive overview of the methodology, an array of competitive responses available to network airlines, and theformulae used to ascertain the strategic capability of network carriers. The results are then presented and discussed in sections 4 and 5, while section 6 outlines the concluding remarks.

\section{Methodology}

This paper aims to establish the strategic capability of Asian network airlines. In this research, the strategic capability of each Asian network airline indicates the degree to which they may be capable of competing with LCCs. The process of ascertaining strategic capability concerns the application of an IATA commissioned methodology implemented by O'Connell (2007, p.298), who sought "to provide a methodology which measured the capability of how much each full service airline could respond to low cost carriers and [to] compare each airline's response strategy." The strategic capability of each incumbent airline is determined by a two phased methodology. Firstly by the strategies that it deems important in competing against low cost carriers and secondly by the difficulties (constraining elements) that it encounters when implementing these strategies.

The starting point of the analysis was the collection of data from questionnaireswith senior management in strategy, finance, or business development from 22 Asian network airlines across three Asia sub-regions. These airlines can be seen in Table 1. Those who participated in this research were mainly contacted via the professional social networking site LinkedIn, 
and later asked to participate. The data used in this paper is just one part of the data obtained from the questionnaires using Bristol Online Survey.

Table 1: List of sampled airlines

\begin{tabular}{|l|l|l|}
\hline Country & Asian sub-region & Network airlines \\
\hline India & South & Air India \\
\hline India & South & Jet Airways \\
\hline Sri Lanka & South & SriLankan Airlines \\
\hline Myanmar & Southeast & Myanmar Airlines (MAI) \\
\hline Vietnam & Southeast & Vietnam Airlines \\
\hline Thailand & Southeast & Thai Airways \\
\hline Malaysia & Southeast & Malaysia Airlines \\
\hline Singapore & Southeast & SilkAir \\
\hline Indonesia & Southeast & Garuda Indonesia \\
\hline Brunei & Southeast & Royal Brunei \\
\hline Philippines & Southeast & Philippine Airlines \\
\hline Macau & Northeast & Air Macau \\
\hline Hong Kong & Northeast & Cathay Pacific \\
\hline Hong Kong & Northeast & Hong Kong Airlines \\
\hline Hong Kong & Northeast & Dragonair \\
\hline Taiwan & Northeast & China Airlines \\
\hline Taiwan & Northeast & EVA Air \\
\hline China & Northeast & Air China \\
\hline China & Northeast & China Eastern \\
\hline China & Northeast & Hainan \\
\hline South Korea & Northeast & Korean Air \\
\hline Japan & Northeast & All Nippon \\
\hline
\end{tabular}

The sampled airlines were each asked about 37 potential competitive responses spread across six response categories which incorporated: productivity; cost and rationalisation; revenue and fare; product; marketing; and other strategically integrated responses. These are listed in listed in Table 2. In total, 74 questions were asked. Firstly, 37 questions were asked on the level of importance allocated by each airline to each of the competitive responses listed in Table 2, which was measured by using a five-point Likert scale (very unimportant to implement; unimportant; neither unimportant nor important; important; and very important) with the level of importance reflecting the degree to which each response may enable the airline to compete effectively with LCCs. Secondly, 37 questions were asked concerning the level of difficulty measured through a five-point Likert scale (very difficult; difficult; neither difficult nor easy; easy; and very easy) that each network airline contemplated when trying to implement each of the competitive responses listed in Table 2. 
Table 2: List of competitive responses

\begin{tabular}{|c|c|}
\hline Competitive response category & 37 Specific competitive responses \\
\hline \multirow[t]{5}{*}{ Productivity responses } & Reducing labour \\
\hline & Increasing aircraft utilisation \\
\hline & Increasing labour productivity \\
\hline & Reducing turnaround times \\
\hline & Increasing seating density \\
\hline \multirow[t]{7}{*}{ Cost and rationalisation responses } & Changing to one fleet \\
\hline & Ability to reduce costs to within $30 \%$ of LCCs \\
\hline & Reducing the use of distribution intermediaries \\
\hline & Negotiating with airports/other suppliers to reduce charges/costs \\
\hline & Unbundling the product \\
\hline & Ability/speed to exit unprofitable markets \\
\hline & Outsourcing particular areas(e.g., ground handling, catering, maintenance) \\
\hline \multirow[t]{6}{*}{ Revenue and fare responses } & Increasing the role of cargo \\
\hline & Revenue from alliance/codeshare partners \\
\hline & Travel policy agreements \\
\hline & Commission-based components(e.g., hotels, car hire, insurance) \\
\hline & Driving more sales through your website \\
\hline & Simplifying fares \\
\hline \multirow[t]{6}{*}{ Product responses } & Increasing product differentiation \\
\hline & Enhancing quality to premium passengers \\
\hline & More emphasis on longer-haul flights \\
\hline & Greater reliance on connecting passengers \\
\hline & Maintaining premium cabins \\
\hline & Frequent flyer programmes \\
\hline \multirow[t]{6}{*}{ Marketing responses } & More effectively targeting chosen market segments \\
\hline & Building value through customer relationship management \\
\hline & More effectively segmenting each market \\
\hline & Leveraging brand strength \\
\hline & Effectively meeting the needs/requirements of customers \\
\hline & Increasing advertising \\
\hline \multirow[t]{7}{*}{ Other strategic responses } & Pursuing mergers and acquisitions \\
\hline & Joint-purchasing agreements with alliance members \\
\hline & Equity investments in other airlines \\
\hline & Diversifying (travel-related businesses, e.g. like hotels or car hire) \\
\hline & High market share in markets with LCC competition \\
\hline & Creating a low-cost subsidiary \\
\hline & Ability of management to quickly introduce changes \\
\hline
\end{tabular}


An objective of the study was to measure the strategic capability of how each full service airline would compete/respond with low cost carriers. O'Connell's (2007) methodology was used as a template as it was endorsed and validated by IATA, which established the mathematical formulae for the strategic capability of incumbent network airlines to compete against low cost carriers using the two phased methodology of establishing competitive responses, which were identified as being effective in competing against LCCs together with the level of difficulty that the incumbent airlines would encounter when instigating these strategies. The airline with the lowest average score for difficulty was classified as the benchmark airline, as this had the least difficulty of all sampled airlines in implementing the competitive responses. Francis et al. (2005) showed that benchmarking is the most common technique for airlines to improve performance. Benchmarking provides a roadmap to airlines to encompass 'best practices' and ways to circumnavigate problems, thereby strengthening their overall competitive advantage. The difference between the benchmark network airline and the other sampled airlines is statistically represented by the average deviance, as shown in Equation 1 as validated by IATA

Equation 1: Calculation of average deviance for level of difficulty

$D_{\mathrm{a}}=\frac{1}{37} \sum_{j=1}^{37}\left(x_{\mathrm{aj}}-X_{\mathrm{j}}\right)=\geq 0$

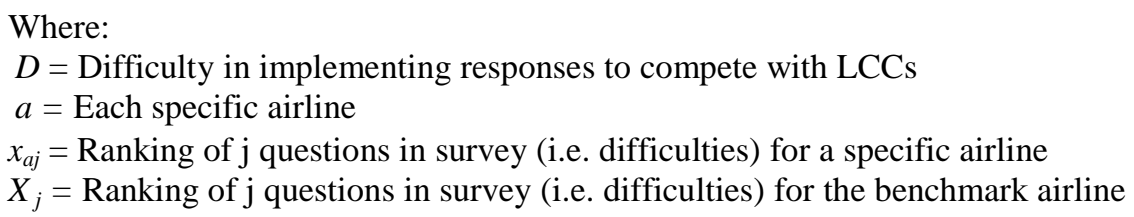

Source: O’Connell (2007); IATA (2007)

The network airline with the highest average score for importance of competitive responses in competing with LCCs was classified as the benchmark airline, as this carrier was the most effective in competing with LCCs. The difference between the benchmark network airline and the other sampled airlines is statistically represented by the average deviance, as shown in Equation 2 as validated by IATA 
Equation 2: Calculation of average deviance for level of importance

$I_{\mathrm{a}}=\frac{1}{37} \sum_{i=1}^{37}\left(y_{\mathrm{ai}}-Y_{\mathrm{i}}\right)=\leq 0$

Where:

$I=$ Importance of responses to compete with LCCs

$a=$ Each specific airline

$y_{i}=$ Ranking of i questions in survey (i.e. importance) for a specific airline

$Y_{i}=$ Ranking of I questions in survey (i.e. importance) for the benchmark airline

Source: O’Connell (2007); IATA (2007)

The strategic capability of each network airline is the difference between the average deviance of the responses that they each consider important to implement in competing with LCCs, and the average deviance of difficulty that each find the responses to be to implement. This can be seen in Equation 3 as validated by IATA

Equation 3: Calculation of strategic capability

$S_{a}=I_{a}-D_{a}$

Source: O'Connell (2007); IATA (2007)

After the strategic capability of each airline has been established, the scores can be related to performance to identify any relationships. This uses a methodology from Robinson (2008). Eight performance areas were used: revenue level; revenue growth rate; cash flow; return on equity; profit margin; net profit from operations; return on investment; and the ability to fund business growth from profits. To determine an airline's overall performance, 16 questions were included in the questionnaire for each of the eight performance areas. Firstly, eight questions were asked about how important each performance area is to the airline (very unimportant; unimportant; neither unimportant nor important; important; very important). Secondly, eight questions were asked about how satisfied the airline currently is with each of the performance areas (very dissatisfied; dissatisfied; neither dissatisfied nor satisfied; satisfied; very satisfied). The results were then averaged across all eight areas of performance for an overall level of performance. 
4. Results of the strategic capability of Asia's incumbent network airlines to compete with Asian LCCs

The results are divided into two parts. Firstly, chapter 4 analyses the strategic capabilities of the sampled Asian network airlines along with how strategic capability varies by sub-region. Chapter 5 then explores the relationship between strategic capability and performance.

\subsection{Strategic capability by airline}

The interrelationship between the level of difficulty and the level of importance of competitive responses for each airline explains the widely varying strategic capabilities to compete with LCCs, as shown in Figure 1. Note that the size of the circles reflects the relative strategic capability of each airline in comparison to the airline with the greatest overall strategic capability. 


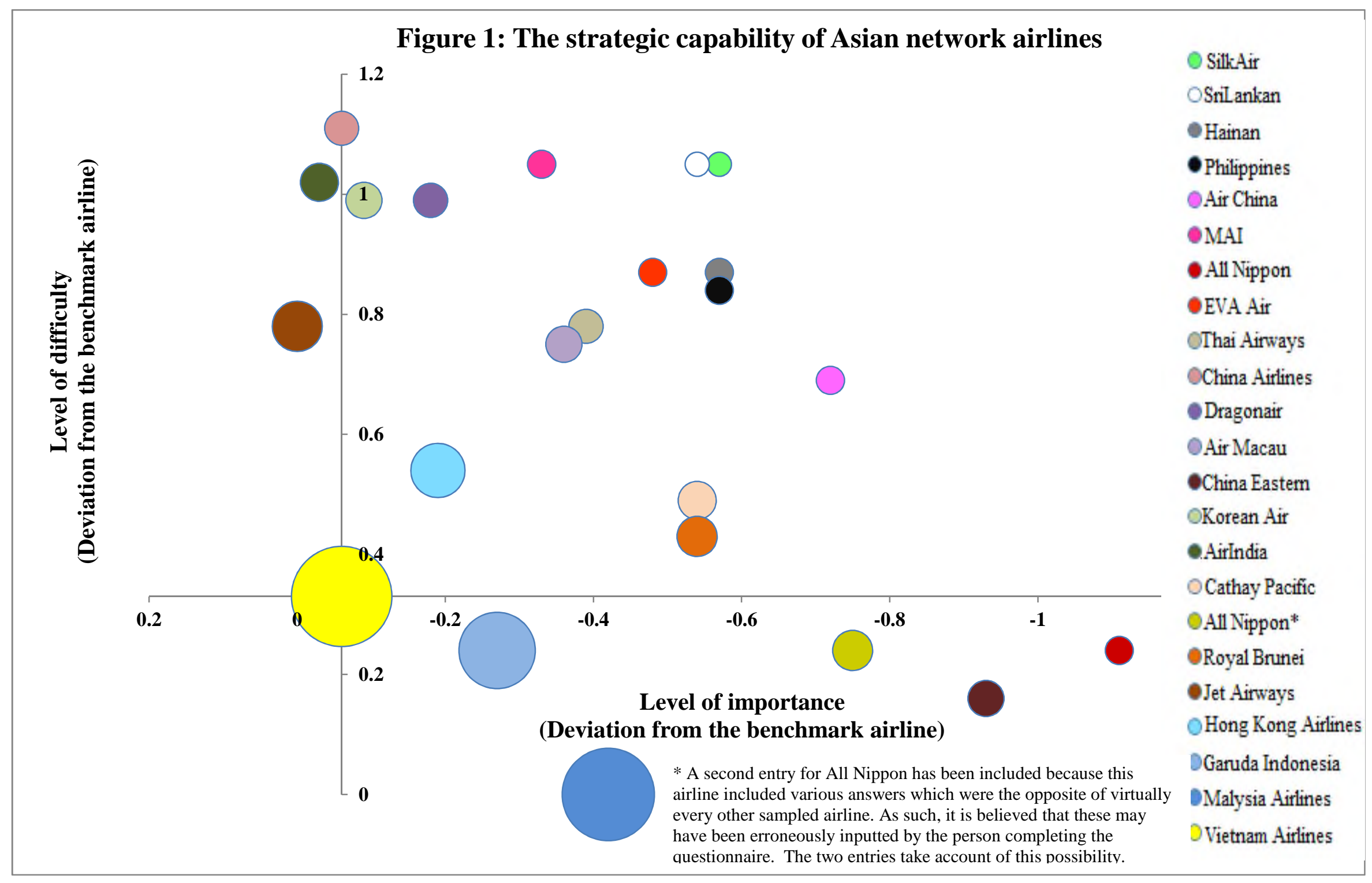


The strategic capabilities of each sub-region in Asiais determined by the average of all analysed airlines within them. Given the use of ordinal data, it is assumed for this purpose that there was commonality as to the interpretation by each respondent of each of the five levels of importance (very unimportant to very important) and difficulty (very difficult to very easy).As expected, network airlines from Southeast Asia have the strongest capability with -0.98 , thus meaning they are better placed, overall, to compete with LCCs than those from South Asia (-1.14) and Northeast Asia (-1.17). The relative strength of network airlines from Southeast Asia is advantageous given this sub-region had an LCC penetration of $58.6 \%$ in 2013, which is almost as high as for South Asia (61.6\%) (CAPA, 2014). That Southeast Asia is best placed is despite SilkAir, the regional and narrowbody operator partner of Singapore Airlines, having the weakest capability of all 22 airlines, with -1.62 and just $24.1 \%$ of the capability of the strongest overall airline, Vietnam Airlines. The very weak position of SilkAir is primarily because it finds all of the analysed responses to be $55.7 \%$ more difficult to implement than the average level of difficulty across all the other sampled airlines. In particular, SilkAir finds these competitive responses to be very difficult to implement: reducing labour; reduce costs to within $30 \%$ of LCCs; changing to one fleet; increasing the role of cargo; increasing product differentiation; and effectively meeting the needs and requirements of its customers. Overall, SilkAir finds these response categories to the most difficult, indicating the widespread nature of its challenges: other strategically integrated responses (4.57 out of five), productivity (4.20), and marketing (4.17).

\subsubsection{Vietnam Airlines}

Vietnam Airlines is positioned as the benchmark airline as the data concluded that it has the strongest strategic capability to compete with LCCs. This suggests that it found all 37 competitive responses to be relatively easy and relatively important to implement when compared against the other sampled Asian network airlines. Its strength in competing with LCCs is fortunate because Vietnam is at the forefront of LCC growth and development within the Asia-Pacific region (Anna.aero, 2011), thus price-based competition is likely to only increase. VietJet is Vietnam's largest LCC and OAG data for 2014 indicates that it has a market share by seat capacity of $13 \%$ overall and $25 \%$ domestically, while CAPA (2014; 2012) anticipates a $50 \%$ share of domestic services in the near future as it is aggressively pushing “to exploit the huge potential of Vietnam's international low-cost airline market". The proliferation of LCCs within Vietnam is set to increase as the country seeks to create a 
liberal operating environment, for example by removing fare caps and regulations (Airline Leader, 2012), whichis a precursor for LCCs to thrive.

The strategic strength of Vietnam Airlinesis aided by the following attributes: it is the only network airline of any real size within Southeast Asia that is entirely government-owned; it is heavily protected; it is dominant within Vietnam as it commands a 50\% market share overall and $62 \%$ share domestically in mid-2014(CAPA, 2014); and because it has a 70\% equity stake in Jetstar Pacific, its low-cost subsidiary. Jetstar Pacific thereby enables indirect participation by Vietnam Airlines in the budget travel segment and when these two airlines are scaled together the combined market share swells to $57.3 \%$ overall and $75 \%$ domestically (CAPA, 2014).

In competing with LCCs and in terms of the six competitive response categories, Vietnam Airlines found product,revenue and fare, and marketing to be the most important to implement. Indeed, it was one of the very few Asian network airlines that found marketing responses to be very important, while it stressed great importance in being customer-driven which may have a positive impact on its PRASM together withachieving greater customer loyalty. It placed slightly less emphasis on the categories of cost and rationalisation and productivity, which was noticeable when compared to the patterns of the responses for the airlines generally. In particular, Vietnam Airlines found that, unlike most of the sampled airlines, the following responses wereall very important for them in competing with LCCs: increasing product differentiation; effectively targeting chosen segments; meeting the needs and requirements of targeted market customers; negotiating with airports and other suppliers to reduce costs; driving commission-based components; and offering convenience in booking travel-related products and services. These strategies have the capability to grow revenues for Vietnam Airlines while providing value-adding ingredients for travellers.

Despite the significance of increasing product differentiation for Vietnam Airlines, it was, surprisingly, one of the few carriers from the sample of 22 airlinesthat found this to be very difficult to achieve. This may hinder its attempts to leverage its geographic position by becoming more of a hub-and-spoke operator, with an increasing number of long-haul services, especially as it is already a latecomer in this respect. Its product is not rated very highly when compared to international standards as it has a 3-starrating while many of its network airline competitors have higher - for example, Thai Airways 4*; Japan Airlines 4*; Cathay Pacific 4*; Asiana 5*; Malaysia 5*; Singapore Airlines 5* (SkyTrax, 2014) (footnote 1 here) - which undermines its attempt to become a more significant airline in the global marketplace. This partially explains why it finds 
differentiation very difficult while at the same time it finds meeting the needs and requirements of its targeted customers difficult. As Vietnam continues to prosper economically more carriers will be attracted by its affluence and the market dominance of the flag carriers will be acutely challenged into the future; clearly, it is important that Vietnam Airlines is able to respond accordingly.

The Vietnamese incumbent found the 37 competitive responses to be easier to implement than the majority of sampled airlines. In particular, it was the only airline of all 22 to consider a low-cost subsidiary to be easy to implement and this strategy of offering a dual-brand increases its differentiation and passenger appeal as it now better meetsthe needs and requirements of a wider range of targeted customers (seePearson and Merkert, 2014). This may enable both airlines to concentrate on their relative strengths as the barriers to entry increase which will potentially dissuade new entrants.

Furthermore, Vietnam Airlines found revenue and fare competitive responses to be easy to implement, especially in terms of growing revenues from cargo; driving more sales through its own website; simplifying fares;and driving commission-based components. Even though Vietnam Airlines had the strongest strategic capability among the sampled incumbents, it would have been even stronger if it could reduce costs to within $30 \%$ of LCCs and increase its product differentiation, which were two key entities that it found very difficult to incorporate.

\subsubsection{Malaysia Airlines}

Malaysia Airlines has the second strongest strategic capability, and at $92.9 \%$ of that of Vietnam Airlines it is near the maximum identified (footnote 2 here).This therefore means that it is better placed to compete with LCCs in comparison to 20 other sampled Asian network airlines. As a country, Malaysia is overwhelmed by LCC activity, as OAG analysis reveals that it's responsible for $50.6 \%$ of the penetration. AirAsia Malaysia is very dominant with $46.0 \%$ market share domestically and $23.7 \%$ internationallyin mid-2014 (footnote 3 here), as compared to Malaysia Airlines' $38.5 \%$ domestically and $26.3 \%$ internationally (CAPA, 2014). AirAsia's core competence is its ethos of cost leadership, while it is asymmetrically positioned at the other end of the airline business model continuum to Malaysia Airlines. In addition, AirAsia is very profitable, fast-growing, entrepreneurial, and challenging (Ong and Tan, 2010). At the same time, Malindo is increasingly growing. This is a joint-venture between Lion Air, which is one of Asia's largest LCCs that currently operatesa fleet of over 100 aircraft with another 520 on order, and Malaysia's National 
Aerospace and Defence Industries (NADI). Malindo is a hybrid operator that offers low average fares witha product that rivals that of Malaysia Airlines, sodelivering a value-formoney proposition to passengers. OAG analysis reveals that it presently has a $5.8 \%$ market share as it only commenced operations in May 2013, but is fast-growing and very threatening for the Malaysian flag carrier. Malaysia Airlines is therefore increasingly squeezed from both perspectives: from very price-sensitive and lower-yielding customers that provide volume; and from those that have a greater willingness and ability to pay. It is Malaysia Airlines, more than most other network airlines, that needs to be able to compete effectively with LCCs.

The position of Malaysia Airlines in Figure 1 indicates that it is the benchmarked airline for level of difficulty, which means that it finds the 37 competitive responses to be easier to implement than any other of the sampled airlines. At the same timeit also finds them to be less important than $30 \%$ of the surveyed airlines. Its strong strategic capability is therefore primarily attributable to the ease with which it finds the competitive responses to implement,which is partly due by having to adapt through necessity, asAirAsia Malaysia is now maturing having reached 12 years in service and is becoming an iconic and prominent business model. In comparison to the overall benchmarked Vietnam Airlines, Malaysia Airlines finds difficulties in:its ability to quickly exit from unprofitable markets; creating a low-cost subsidiary; using and leveraging FFPs; simplifying fares; and increasing the role of cargo. Malaysia Airline finds productivity, cost and rationalisation, and marketing response easier to implement than Vietnam Airlines, the airline with the strongest overall strategic capability. This ease is especially (footnote 4 here) in terms of unbundling the product; the ability to reduce costs within $30 \%$ of LCCs; travel policy agreements; increasing product differentiation; effectively targeting chosen segments; and meeting the needs and requirements of targeted customers.Research on Malaysia Airlines has concluded that the airline has adequately met the needs of the passenger requirements in terms of service quality and schedule, while Air Asia's has done so through the single entity of fares (Suki, 2014; Ong and Tan, 2010; O'Connell and Williams, 2005).

Despite Malaysia Airlines' strong strategic capability, the airline is unprofitable andhas lost $\$ 1.3$ billion over the past three years. It lost $\$ 354$ million in its 2013 financial year, which was more significant than in 2012 (Malaysia Airlines, 2014).Malaysia Airlines (2014) attributed theselosses to an array of issues but prioritised: the depreciation of the Ringgit against the US dollar generated large foreign exchange losseswhich is highly problematic as almost $60 \%$ of its costs are in US Dollars, which significantly increases the cost base; 
escalating operating costs such as fuel which increased by almost $11 \%$ over the twelve-month period between 2012-2013; and lower yields from intensifying competition from both Gulf and European airlines explicitly attacking its long-haul operations, and LCCs continuing to encroach onto its short-haul markets. It is clear that LCCs have significantly impacted Malaysia Airlines, and it urgently needs a solid platform in which to launch hard-hitting strategies to outflank its advancing and relentless competition.

\subsubsection{Thai Airways}

Thai Airways, with its lower strategic capability and greater exposure to LCCs, is especially vulnerable, as OAG data illustrates that, in mid-2014,Thai AirAsia possessesgreater market share domestically than Thailand's flag carrier with $26.9 \%$ against $21.8 \%$ respectively. Thai Airways is also beginning to struggle in the international sector as its market shareis now only $10 \%$ morethan Thai AirAsia and is very concerned as it continues to lose ground. Thai Airways will be increasingly pressured following the introduction in December 2013 of another Asian LCC in Thai Lion, which focuses solely on low fares under a strict cost leadership business model. Combined,Thai Lion and Thai AirAsia will introduce16 new aircraft in 2014and have the option to scale this much higher in subsequent years. Thus it is imperative that Thai Airways responds expeditiously and appropriately to this influx. This questionnairerevealed that, unlike most Asian network airlines, Thai Airways considers the following specific responses to be very important in competing with LCCs: negotiating with airports and other providers to reduce charges and costs; outsourcing particular areas; revenue from alliance and codeshare partners; using and leveraging their FFP; and creating a low-cost subsidiary.

Furthermore, Aspire Aviation (2013) identified that Thai Airways "must gain efficiencies wherever it can and make some bold moves." This has recently included the offering for sale of 18 older and fuel-inefficient aircraft. Thai Airways' bold move emanated by setting up two subsidiary airlines with lower cost structures than the incumbent through the creation of Thai Smile, a light-premium hybrid operator, and through its domestic LCC subsidiary,Nok Air.Theseseparate brands each have unique products and value propositions that arefocused on particular segments (Pearson and Merkert, 2014). Nok Air has become Thailand's most profitable operator, with an 11\% net margin in 2013 (ACI, 2013), and Taylor (2013) shows it anticipates adding 12 new aircraft by 2015 for a total of 33. The three carriers in the Thai Airways group have an overall market share(domestic and international) of $36.6 \%$ in mid2014 (CAPA, 2014), about double Thai AirAsia's. Nevertheless, Thai Airways' own strategic 
capability is $6.7 \%$ below the average capability of all 22 airlines, and this clearly must be strengthened if it is to survive and prosper as Thailand's domestic and international markets inevitably become more competitive.

\subsubsection{Philippine Airlines}

The Philippines has the largest infiltration of LCCs than any other Asian country and Philippine Airlines is pivoted in the centre of this mass invasion. The income distribution in the Philippines is distorted as the upper $50 \%$ of households have $80 \%$ of the income and the highest $10 \%$ accounted for $34 \%$ of the consumption (Africa, 2011). Therefore, the majority of the Filipino population or travellers to the Philippines are budget conscious which has inturn triggered the rapid expansion of LCCs, as CAPA (2014)determined that LCCs hold around 92.0\% of the domestic seat capacity, which is the world's highest penetration, and the LCCs control around one-third of the International market in 2013. Despite this, Philippines Airlines has weakstrategic capability, with just $27.7 \%$ of the capability of the benchmarked airline, Vietnam Airlines. With the fourth lowest capability of all 22 airlines, Philippines Airlines significantly underperforms compared to its peers and struggles considerably in competing with LCCs. Manuela (2011) found thatthe Philippine-domiciled carriers must discount heavily in order to stimulate passenger activity. A passenger survey of passengers travelling on Philippine Airlines in 2012 undertaken by O'Connell and Vanoverbeke (2014) found that the fare was the most important purchasing criteria for economy passengers flying to the Philippines.

Philippine Airlines found the 37 competitive responses significantly more difficult to implement and equally less important than the benchmark airline, Vietnam Airlines. The Philippine incumbent found the following responses to be especially difficult: ability and speed to exit unprofitable markets; increasing seating density; increasing the role of cargo; more effectively segmenting each market; and building value through CRM. Philippine Airlines also found it very difficult to generate more connecting passengers, which is a proposition strongly supported by O'Connell and Vanoverbeke (2014) who found that just 13.4\% of Philippine Airlinespassengers from its North American routes transferred in Manila to other Filipino destinations in 2012. The situation is further exacerbated as the incumbent is not currently a member of any of the three global alliances (accounting for $61 \%$ of the global traffic) which would allow Philippine Airlines to connect and transfer passengers to their vast networks.Philippine Airlines indicated that there were a number of issues that it deemed unimportant when competing with LCCs which included: changing to one fleet: negotiating 
with airports and other providers to reduce costs;and commission-based components. Meanwhile, other concerns were raised that were categorised as even less important and comprised: reducing labour; the ability to quickly introduce changes; leveraging brand strength; outsourcing; and leveraging their FFP. These are all essential strategies that should be prioritised when competing against LCCs, for otherwise Philippine Airlines will continue to struggle in its pursuit of combating its low fare aggressors. Nevertheless, the Philippine flag carrier placed greater emphasis on certain responses than the airline with the strongest overall capability, notably: revenue from alliance or codeshare partners; more emphasis on longer-haul flights; greater reliance on connecting passengers; reducing the use of distribution intermediaries; andincreasing seating density, which demonstrates its intent to strategically position itself more into the long haul markets where it can avail of feed traffic from partners. Clearly it has no long-term strategic plan in place in dealing with LCCs, which is a dangerous prognosis.

\subsubsection{Jet Airways and Air India}

Jet Airways and Air India placed a very similar higher level of importance on particular competitive responses than Vietnam Airlines had emphasised. However, they also found responses to be considerably more difficult to implement. They particularly stressed the importance of reducing the use of distribution intermediaries; simplifying fares; maintaining premium cabins; and leveraging brand strength. Jet Airways and Air India found simplifying fares to be very important with virtually every other sampled airline considering it less important.O'Connell et al (2013) demonstrated that fares on Indian domestic markets have fallen by $57 \%$ from 2005 to 2009, while IATA (2012) reported that the average Indian ticket price of $\$ 95$ is about $\$ 11$ below that of the cost to break-even, which highlights the significance of fare structures and their associated issues. Both airlines have been slow at implementing changes, which largely accounts for their poor financial performance. For example, Air India lost an accumulated \$3.2 billion in the three financial years ending March 2014, and Jet Airways lost \$919 millionin the same period (CAPA, 2014a; CAPA, 2014b). Their slowness in implementing changes is especially disadvantageous given the excessive competition from LCCs that they have experienced, thus the need to strengthen their capabilities, beginning with cost-cutting, if they are to clawback market share and to strengthen their competitive advantage. Indeed, Air India, in its committee report on its cost cutting programme, and Jet Airways, in its turbine restructuring programme, both emphasised the significance of eliminating commissions for bookings and growing direct sales. The 
responses on which they place greater emphasis partly indicates their similar approaches to restructuring: adopting certain fundamental LCC practices while retaining the core elements of network airlines, thereby somewhat hybridising. This approach has been successfully implemented by Aer Lingus.

Overall, network airlines from South Asia have nearly the weakest strategic capability of all three sub-regions, at -1.14. That this sub-region also has the highest LCC penetration 61.6\% (CAPA, 2014) - clearly indicates the challenges faced by airlines from this area. This is especially the case for Air India and SriLankan, the latter the second least capable of competing with LCCs (-1.59). Indeed, they desperately need to be able to effectively respond to LCCs but they are unable to do so

\subsubsection{Cathay Pacific and Hong Kong Airlines}

Network airlines in Hong Kong are very vulnerable to new LCC entry from the insatiable growth of LCCs and because LCCs in Hong Kong in 2013 had just 5\% market share (CAPA, 2014), with Hong Kong “one of the bigger pieces of the puzzle that's been missing from the LCC map" (Wang and Lee, 2014). Their vulnerability is not just because of increased price competition but also, and perhaps more importantly, to the declining number of slots and gates, thereby reducing expansion potential. Will Horton, a senior analyst based in Hong Kong for the Centre for Aviation, said that "Cathay is extremely worried" (Wang and Lee, 2014). However, both Cathay Pacific and Hong Kong Airlines have above-average strategic capabilities, at -1.03 and -0.73 respectively, so are better placed than many to compete with LCCs. Hong Kong Airlines' overall position is strengthened further because Hong Kong Express has been modified into an LCC, so it is now effectively its low-cost subsidiary. Thus, Hong Kong Airlines will focus upon the premium segment while Hong Kong Express targets leisure and labour traffic. In contrast, Cathay Pacific has no plan for its own low-cost subsidiary, and will instead make necessary changes itself to increase its competitiveness, particularly regarding adjusting to customer requirements (IATA, 2013). Indeed, this questionnaire established that Cathay Pacific finds increasing product differentiation and enhancing quality to premium passengers to be both easy and very important.

Despite the relative strength of Cathay Pacific and Hong Kong Airlines, network airlines within Northeast Asia have the lowest strategic capability of all sub-regions. This suggests that they are not ready or able to effectively compete with LCCs, which partly explains why so many of them have created or have announced or planned low-cost subsidiaries (footnote 5 here), thereby believing they need not instigate so many changes themselves. However, they 
would benefit more from strengthening their own existence, thus increasing their capability to compete by reducing costs, increasing efficiency and productivity, or adapting their product and marketing responses to better reflect the changing reality. This may also assist in increasing barriers to entry, thereby potentially reducing the likelihood of new entry.

\section{Strategic capability and performance}

The identified strategic capability of all sampled network airlines was then measured against their overall performance (the level of importance and current satisfaction with each of the eight performance areas and then averaged). This can be seen in Figure 2.Vietnam Airlines was measured as the benchmark airline as it had the strongest overall strategic capability, and all the other data points for the other airlines were rescaled accordingly. As the benchmark airline, Vietnam Airlines is set to $100 \%$ because otherwise all the data points would become clustered in the centre of the diagram and may therefore be very difficult to interpret. 
Figure 2: Strategic capability and network airline performance

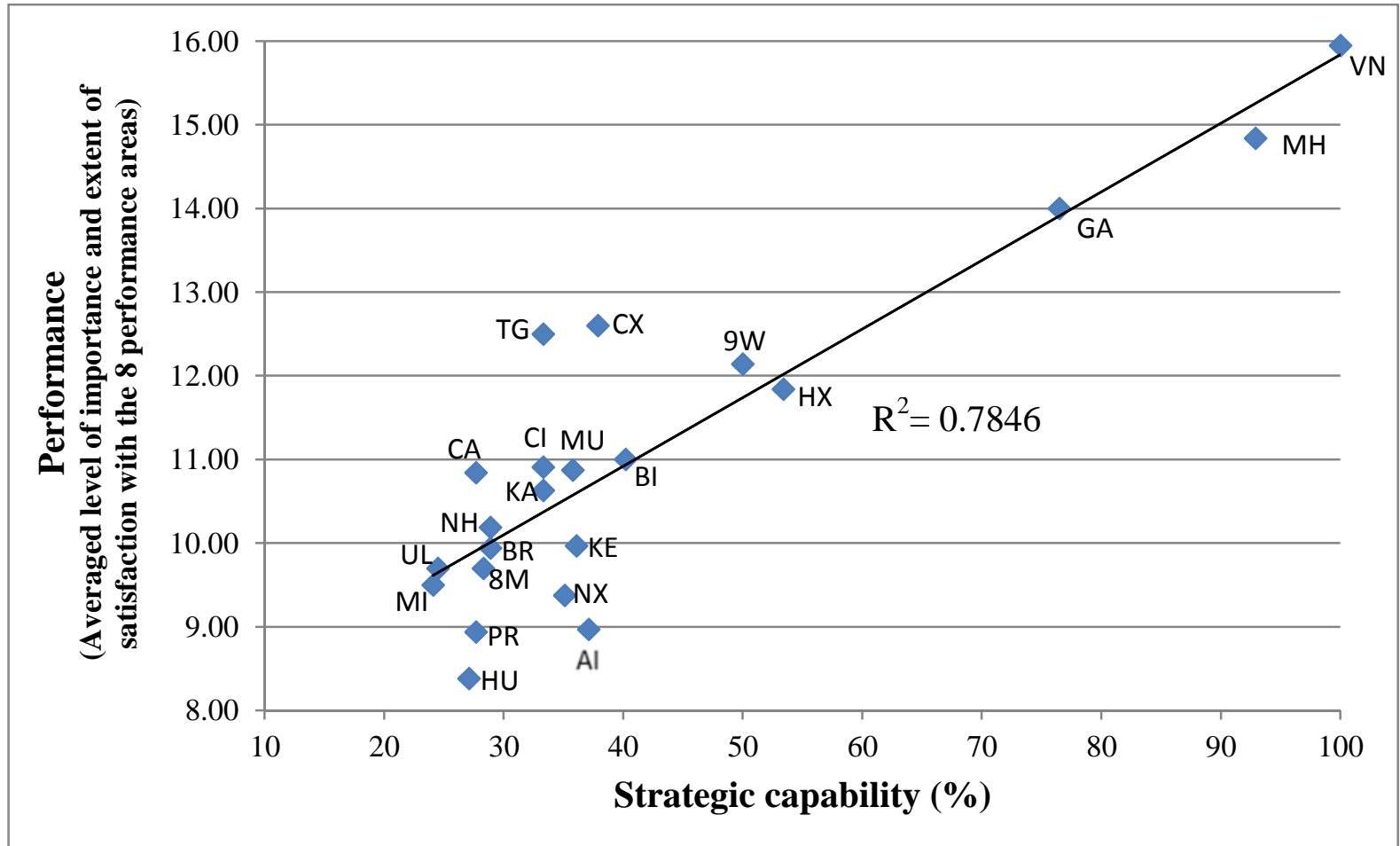

Note: VN = Vietnam Airlines; $\mathrm{MH}=$ Malaysia Airlines; GA = Garuda Indonesia; HX = Hong Kong Airlines; 9W = Jet Airways; CX = Cathay Pacific; $\mathrm{TG}=$ Thai Airways; $\mathrm{BI}=$ Royal Brunei; $\mathrm{MU}=\mathrm{China}$ Eastern; $\mathrm{CI}=$ China Airlines; KA = Dragonair; $\mathrm{CA}=$ Air China; NH = All Nippon; BR = EVA Air; KE = Korean Air; NX = Air Macau; AI = Air India; HU = Hainan Airlines; PR = Philippine Airlines; MI = SilkAir

There is a direct correlation between the overall performance and the strategic capability of the Asian network airlines. Vietnam Airlines and Malaysia Airlines, for example, had performance rankings of 15.95 and 14.84 respectively out of a maximum 16.00,and they had the highest strategic capabilities. These airlines placed $28.9 \%$ more emphasis on the importance of the eight performance metrics (revenue level, revenue growth rate, cash flow, return on equity, profit margin, net profit from operations, return on investment, and the ability to fund business growth from profits) than their current levels of satisfaction with them. In contrast, SilkAir and SriLankan, two airlines with very weak capability, had performance of 9.50 and 9.70 respectively out of 16.00 . These two airlines consider the eight performance metrics to be $24.5 \%$ less important than Vietnam Airlines and Malaysia Airlines, and they are $3.3 \%$ less satisfied with them. The correlation of determination between the performance rankings and strategic capability is 0.7846 which suggests that airlines with strong strategic capabilities, and thus strong abilities to compete with LCCs, may expect high overall performance by this measure, and those with low strength may expect low performance. 


\section{Conclusions}

The worldwide LCC penetration rate has grown from 8\% in 2001 to $26.3 \%$ in 2013. Within Asia-Pacific, it has increased from $1.1 \%$ to $24.5 \%$ in this time period. South and Southeast Asia are at the forefront of LCC development within Asia, with around double the worldwide rate. LCCs there have grown exponentially, and growth in the past four years, in particular, has been considerable. This is forecast to continue as there are still many opportunities, especially given population growth, already large populations, rising disposable incomes, and often comparatively poor surface alternatives. That Northeast Asia has an LCC penetration of less than half the worldwide average indicates the potential of its own further developments, which are increasingly being undertaken.

Irrespective of sub-region, network airlines face an increasingly competitive external environment, which potentially results in many negative implications. Theoretically, it also offers a variety of opportunities, particularly in terms of determining precisely their strategic intention and positioning, refocusing upon their coreand away from LCCs to achieve greater PRASM, and rationalising costs and becoming more productive. There are many ways by which network airlines may respond to LCCs, and this paper looked at 37 competitive responses across six response categories to establish how capable 22 Asian network airlines are in competing with LCCs. The determination of capability is an important starting point for them.

This paper found that the strategic capability varies widely by airline, which is to be expected given the differing levels of importance and difficulty placed by each airline on the competitive responses. The strength of strategic capability does not directly reflect the degree of competition faced by LCCs, for it varies widely. In terms of those that presently compete strongly with LCCs, Vietnam Airlines, Malaysia Airlines, and Garuda Indonesia all are reasonably well placed to compete as they have comparatively strong strategic capabilities. In comparison, Air India, Thai Airways, Philippine Airlines, SilkAir all have notably weaker capabilities and so are more exposed. Nevertheless, the possession of a strong capability does not necessarily mean that it is fully or properly leveraged.

Those network airlines in countries that are yet to see much LCC activity - including China, Hong Kong, Taiwan, Myanmar, and Japan - need to strengthen their strategic capabilities asthey are relatively weak. Indeed, Northeast Asia was found to have the weakest overall strategic capability of all three regions. The reasonably strong correlation between strategic capability and overall performance indicates the imperativeness of 
strengthening and exploiting strategic capability. This will become increasingly important as LCCs further penetrate.

\section{References}

ACI (2013),International Air Travel Update, (http://www.acina.org/sites/default/files/kaplan_final_slides.pdf, accessed 1st June, 2014).

Africa, T. (2011), Family Income Distribution in the Philippines, 1985-2009: Essentially the Same, (http://makuhari.wordpress.com/2011/03/07/family-income-distribution-in-thephilippines-1985-2009-essentially-the-same/, accessed 31 January 2014).

Airbus (2013), Global Market Forecast: 2013-2032,(available at http://www.airbus.com/company/market/forecast/, accessed 5th June 2014).

Airline Leader (2014), Northeast Asia outlook, (available at http://www.airlineleader.com/regional-focus/north-asia-outlook-2014, accessed 6th June, 2014).

Airliner Leader (2013), A Growth Upside Like Never Before: North Asia's LCCs, (http://www.airlineleader.com/this-months-highlights/a-growth-upside-like-never-beforenorth-asias-lccs, accessed $4^{\text {th }}$ August, 2014).

Airline Leader (2012), Vietnam: Sowing the Seeds for Future Growth, (http://www.airlineleader.com/country-in-focus/vietnam-sowing-the-seeds-for-future-growth, accessed 6th June, 2014).

Anna.aero (2011), Vietnam's Traffic Continues to Boom as Country Prepares for London Services, (http://www.anna.aero/2011/12/01/vietnam-traffic-continues-to-boom-as-countryprepares-for-london-services/,accessed $6^{\text {th }}$ June, 2014).

Aspire Aviation (2013), Thai Airways Pressured by an Increasingly Competitive Market, (http://www.aspireaviation.com/2013/09/26/thai-airways-pressured-by-an-increasinglycompetitive-market/,accessed $6^{\text {th }}$ June, 2014).

Aviation Week (2014), LCC Showdown Looms in Southeast Asia, (http://aviationweek.com/awin/lcc-showdown-looms-southeast-asia, accessed $5^{\text {th }}$ August, 2014).

Berdy, P. and Zhong, F. (2013), China's Aviation Renaissance, volume 2, Ascend for Aviation.

CAPA (2014a), Air India profile, Subscription Only.

CAPA (2014b), Jet Airways profile, Subscription Only.

CAPA (2014), Low-Cost Carrier Data, Subscription Only. 
CAPA (2013), VietJet Starts to Exploit Huge Potential of Vietnam's International Low-Cost Airline Market, (http://centreforaviation.com/analysis/vietjet-starts-to-exploit-huge-potentialof-vietnams-international-low-cost-airline-market-98404, accessed 1st June, 2014).

CAPA (2009), How the Legacy Full ServiceAirlines have Responded to Rising LCC Competition, (http://www.centreforaviation.com/analysis/how-the-legacy-full-serviceairlines-have-responded-to-rising-lcc-competition-14504, accessed 3rd January, 2014).

China Airlines (2014), China Airlines and Tigerair Set to Launch Budget Carrier/Low Cost Carrier Tigerair Taiwan, (http://www.chinaairlines.com/en/newsen/newsen000859.htm, accessed 5th June, 2014).

Doganis, R. (2006), The Airline Business, second edition, Routledge, Abingdon.

Dutton, J. E. and Jackson, S. E. (1987), Categorising Strategic Issues: Links to Organisational Action, Academy of Management Review, volume 12, p.p.76-90, DOI:10.5465/AMR.1987.4306483.

Forsyth, P. (2005), Competition Versus Predation in Aviation Markets: A survey of experience in North America, Europe, and Australia, Ashgate, Aldershot.

Francis, G., Humphreys, I., Fry, J. (2005). The Nature and Prevalence of the Use of Performance Measurement Techniques by Airlines, Journal of Air Transport Management, volume11, pp.207-217, DOI: dx.doi.org/10.1016/j.jairtraman.2004.10.003.

$\mathrm{Fu}, \mathrm{X}$. and Oum, T. (2014), Air Transport Liberalization and its Effects on Airline Competition and Traffic Growth: an overview, in Peoples, J. (ed), Advances in Airline Economics, Emerald, pp.11-44.

Gross, S. and Luck, M. (2013), The Low Cost Carrier Worldwide, Ashgate, Aldershot.

Hamel, G. and Prahalad, C. K., (2013), Creating Global Strategic Capability, in: Wood, N. and Vahlne, J. E. (eds), Strategies in global competition, Routledge, Abingdon.

Hanaoka, S., Takebayashi, M., Ishikura, T., Saraswati, B. (2014).Low-Cost Carriers Versus Full Service Carriers in ASEAN: The Impact of Liberalization Policy on Competition, Journal of Air Transport Management, volume 40, pp. 96-105, DOI: 10.1016/j.jairtraman.2014.06.008.

Holloway, S. (2008), Straight and Level: Practical Airline Economics, third edition, Ashgate, Aldershot.

IATA (2013), Cathay Pacific: Celebrate Differences, (http://www.iata.org/publications/airlines-international/april-2013/Pages/ceo-interviewcathay.aspx, accessed 6th June, 2014).

IATA (2012). Special Report: Putting the Pieces Together, (http://trainingwww.iata.org/publications/airlines-international/october-2012/Pages/india.aspx, accessed $4^{\text {th }}$ June, 2014). 
IATA (2007). O'Connell correspondence with IATA executives on Airline Strategy - found in O'Connell, J. F. (2007), The Strategic Response of Full Service Airlines to the Low Cost Carrier: Threat and the Perception of Passengers to Each Type of Carrier, $\mathrm{PhD}$ thesis, Cranfield University.

Johnson, G., Scholes, K. and Whittington, R. (2007), Exploring Corporate Strategy, eighth edition, Pearson Education, Harrow.

Klophaus, R. Conrady, R., and Fichert, F. (2012), Low Cost Carriers Going Hybrid: Evidence from Europe, Journal of Air Transport Management, volume 24, pp.54-58, DOI: 10.1016/j.jairtraman.2012.01.015

Malaysia Airlines, 2013 Annual Report, (available at http://ir.chartnexus.com/mas/report.php,accessed 4th June, 2014).

Manuela, W.S. (2011), Factors Affecting Airline Profits: Evidence from the Philippines, Journal of Applied Business Research, volume 27,pp 17-22.

Markides, C. (2006), Disruptive Innovation: In Need of Better Theory, Product Innovation Management, volume 23, pp.19-25, DOI: 10.1111/j.1540-5885.2005.00177.x

Merkert, R. and Pearson, J. (2014),A Non-parametric Efficiency Measure Incorporating Perceived Airline Service Levels and Profitability, Journal of Transport Economics and Policy [in press].

Roberts, N. and Stockport, G. J. (2014), Defining Strategic Flexibility, in: Sushil, A. and Stohr, E. A. (eds), The Flexible Enterprise, Springer, India.

OAG (Official Airline Guide), Airline Capacity Database, Subscription Only.

O'Connell, J.F. and Vanoverbeke, K. (2014).Philippine Airlines, Flying in a changing landscape, Journal of Tourism Economics, DOI:http://dx.doi.org/10.5367/te.2014.0403.

O'Connell, J. F., Krishnamurthy, P., Warnock-Smith, D., Lei, Z., Miyoshi, C. (2013), An investigation into the core underlying problems of India's airlines, Transport Policy, volume 29, pp.160-169, DOI: 10.1016/j.tranpol.2013.05.002.

O'Connell, J. F. (2007), The Strategic Response of Full Service Airlines to the Low Cost Carrier: Threat and the Perception of Passengers to Each Type of Carrier, PhD thesis, Cranfield University.

O’Connell, J.F. and Williams, G. (2005).Passengers' Perceptions of Low Cost Airlines and Full Service Carriers: A Case Study Involving Ryanair, Aer Lingus, Air Asia and Malaysia Airlines, Journal of Air Transport Management, volume 11, pp. 259-272, DOI:

10.1016/j.jairtraman.2005.01.007. 
Ong, W. L. and Tang, A. K. G. (2010), A Note on the Determinants of Airline Choice: The Case of Air Asia and Malaysia Airlines, Journal of Air Transport Management, volume 16pp.209-212, DOI: 10.1016/j.jairtraman.2009.06.001.

Pearson, J. and Merkert, R. (2014),Airlines-within-airlines: ABusiness Model Moving East, Journal of Air Transport Management, volume 38, pp.21-26, DOI: 10.1016/j.jairtraman.2013.12.014

Robinson, M. S. (2008), Understanding the Resource-Based View: Implications of Methodological Choice and a New Creative Context, PhD thesis, Queensland University of Technology.

Rumelt, R. (2011) Good strategy, bad strategy, Profile Books, London

Ryans, A., (2009), Beating LowCost Competition: How Premium Brands can Respond to Cut Price Rivals, John Wiley \& Sons, Chichester.

Schofield, A. (2013), Taiwan-based Carriers Unveil LCC Start-Up Plans,(http://aviationweek.com/awin/taiwan-based-carriers-unveil-lcc-start--plans, accessed 6th June, 2014).

SkyTrax (2014), Vietnam Airlines, (http://www.airlinequality.com/Airlines/VN.htm accessed 5th June, 2014).

Suki, N. M. (2014),Passenger Satisfaction with Airline Service Quality in Malaysia: A Structural Equation ModellingApproach, Research in Transportation Business \& Management, volume 10,pp.26-32, DOI: 10.1016/j.rtbm.2014.04.001.

Tan, A. K. J. (2014), The ASEAN Single Aviation Market: Liberalizing the Airline Industry, ERIA Policy Brief, June.

Taneja, S. Pryor, M. G., Sewell, S., and Recuero, A. M. (2014), Strategic Crisis Management: A Basis for Renewal and Crisis Prevention, Journal of Management Policy and Practice, volume 15, pp.78-85.

Taneja, N. K. (2010), Looking Beyond the Runway: Airlines Innovating with Best Practices while Facing Realities, Ashgate, Aldershot.

Taylor, E. (2013),Nok Air to Add 12 Aircraft by 2015, (http://www.flightglobal.com/news/articles/nok-air-to-add-12-aircraft-by-2015-390456/, accessed $4^{\text {th }}$ August).

Teece D. J. (2007), Explicating DynamicCapabilities: The Nature and Micro Foundations of (Sustainable) Enterprise Performance, Strategic Management Journal, volume 28, pp.13191350, DOI: $10.1002 / \mathrm{smj} .640$.

Thompson, S. (2013), Myanmar: Yangon International Airport Prepares for Huge Passenger Growth, (http://www.airport-world.com/component/k2/item/2761-myanmar-yangoninternational-airport-prepares-for-huge-passenger-growthaccessed 6th June). 
Wang, J. and Lee, S. (2014), Asia's Budget Airline Invasion, (available at http://www.businessweek.com/articles/2014-02-13/asias-budget-airline-invasion-cathaypacific-defends-hong-kong, accessed 6th June, 2014).

Zhang, A., Hanaoka, S., Inamura, H., and Ishikura, T. (2009), Low Cost Carriers in Asia: Deregulation, Regional Liberalization and Secondary Airports, Research in Transportation Economics, volume 24, pp.36-50, DOI: 10.1016/j.retrec.2009.01.001.

\section{Footnotes:}

1 The official SkyTrax ranking has existed since 1999 and is based on looking at the standards of 800 different items/areas across an airline's frontline product and staff service areas and also the airport and cabin service environments.

2 The data for Malaysia Airlines was obtained prior to the loss of flights MH370 and MH17

3 The inclusion of AirAsia X, AirAsia's medium- and long-haul subsidiary that is based in Malaysia, means thatthe Malaysia-based elements of the AirAsia Group has an international market share of 31.7\%. The inclusion of Indonesia AirAsia increases this to 37.9\% (CAPA, 2014)

4 For instance, where there is at least a two-point difference, for example Malaysia Airlines deeming a response to be neither easy nor difficult (score of three of five) and Vietnam Airlines considering it very difficult (score of five). All responses are at least difficult for Vietnam Airlines

5 For example, Air India Express; Nok Air; Jetstar Asia; Tigerair; Citilink; Jetstar Pacific; Hong Kong Express; Tigerair Taiwan; V Air; PAL Express; Air Busan; Jin Air; and Peach. Various low-cost subsidiaries are planned in China, for example China United (from China Eastern) and Jiuyuan Airlines (from Juneyao) 
2015-03-30

The strategic capability of Asian network airlines to compete with low-cost carriers

Pearson, James

Elsevier

James Pearson, John F. O'Connell, David Pitfield, Tim Ryley, The strategic capability of Asian network airlines to compete with low-cost carriers, Journal of Air Transport Management, Volume 47, August 2015, Pages 1-10 http://dx.doi.org/10.1016/j.jairtraman.2015.03.006.

Downloaded from Cranfield Library Services E-Repository 